\title{
Delimitation of potential areas for groundwater recharge in the Toluca Valley aquifer
}

\section{Delimitación de zonas con potencial de recarga hídrica en el acuífero del Valle de Toluca}

SERVÍN-PRIETO, Alan Joel†*, FRÍAS-RAMÍREZ, José Ernesto, SIFUENTES-MORÍN, Norma Guadalupe and MONTEMAYOR-TREJO, José Alfredo

\begin{abstract}
Instituto Tecnológico de Torreón. Carretera Torreón-San Pedro de las Colonias Km 7.5, Ejido Ana, CP 27170. Torreón, Coahuila
\end{abstract}

\author{
ID $1^{\text {st }}$ Author: Alan Joel, Servín-Prieto / ORC ID: 0000-0002-5534-7875, CVU CONACYT ID: 255753 \\ ID $1^{\text {st }}$ Coauthor: José Ernesto, Frías-Ramírez / ORC ID: 0000-0002-6631-6599, CVU CONACYT ID: 67627 \\ ID $2^{\text {nd }}$ Coauthor: Norma Guadalupe, Sifuentes-Morín / ORC ID: 0000-0003-4724-5294, CVU CONACYT ID: 713430 \\ ID $3^{\text {rd }}$ Coauthor: José Alfredo, Montemayor-Trejo / ORC ID: 0000-0001-8222-286X, CVU CONACYT ID: 201396
}

DOI: $10.35429 / J U R R E .2020 .7 .4 .30 .36$

Received July 11, 2020; Accepted November 27, 2020

\begin{abstract}
Water is one of the most important natural resources for all living beings, it is essential for food security and the health of ecosystems. It occupies $75 \%$ of the planet's surface, however, only $3 \%$ is available to man for consumption. Mexico has 653 aquifers. $39.1 \%$ of the total volume of these is concessioned for agricultural irrigation uses. According to studies carried out by the National Water Commission, as of 2018, of the 653 units, 105 aquifers are reported in a state of overexploitation. The objective of this research was to implement the guide for the identification of areas with potential for water recharge, developed by the Tropical Agronomic Center for Research and Teaching of Costa Rica, which proposes the delimitation of potential recharge areas through geospatial information considering the topics of edaphology, geology, land use and vegetation, as well as relief and slopes. The results obtained show that in the Toluca Valley aquifer there are five categories of possibility of water recharge, although the moderate possibility prevails (59.4\%), followed by a low possibility of recharge occurrence $(21.0 \%)$, very low possibility $(16.7 \%)$, high possibility (1.6\%) and very high possibility (1.2\%).
\end{abstract}

Hydric recharge, Aquifer, GIS

\begin{abstract}
Resumen
El agua es uno de los recursos naturales mas importantes para todo ser vivo, es indispensable en la seguridad alimentaria y la salud de los ecosistemas. Ocupa el $75 \%$ de la superficie del planeta, sin embargo, solo el $3 \%$ esta a disposición del hombre para su consumo. México cuenta con 653 acuíferos. El 39.1\% del volumen total de estos, es concesionado para usos de riego agrícola. De acuerdo con estudios realizados por la Comisión Nacional del Agua, al 2018, de las 653 unidades, 105 acuíferos se reportan en estado de sobreexplotación. El objetivo de esta investigación fue implementar la guía de identificación de zonas con potencial de recarga hídrica, desarrollada por el Centro Agronómico Tropical de Investigación y Enseñanza de Costa Rica, en la que se propone la delimitación de zonas potenciales de recarga mediante información geoespacial considerando los temas de edafología, geología, uso de suelo y vegetación, así como también de relieve y pendientes. Los resultados obtenidos muestran que en el acuífero del Valle de Toluca se dan las cinco categorías de posibilidad de recarga hídrica, aunque predomina la posibilidad moderada $(59,4 \%)$, seguida por una baja posibilidad de ocurrencia de recarga $(21,0 \%)$, muy baja posibilidad $(16,7 \%)$, alta posibilidad $(1,6 \%)$ y muy alta posibilidad $(1,2 \%)$.
\end{abstract}

Recarga hídrica, Acuífero, SIG

Citation: SERVÍN-PRIETO, Alan Joel, FRÍAS-RAMÍREZ, José Ernesto, SIFUENTES-MORÍN, Norma Guadalupe and MONTEMAYOR-TREJO, José Alfredo. Delimitation of potential areas for groundwater recharge in the Toluca Valley aquifer. Journal-Urban-Rural and Regional Economy. 2020. 4-7: 30-36

\footnotetext{
* Correspondence to Author (email: alanjservin@ gmail.com)

$\dagger$ Researcher contributing as first author.
} 


\section{Introduction}

According to the statistics of water in Mexico (2018), the Mexican Republic has a surface area of 1,964 million $\mathrm{km} 2$, of which $99.7 \%$ corresponds to the continental surface, while the remaining $0.3 \%$ corresponds to island areas. Regarding surface water, in Mexico water resources are organized by hydrological basins and in aquifers if it refers to groundwater. The basins are considered as natural units of the land, defined by the existence of a division of the surface water resources due to the conformation of the relief. The National Water Commission (CONAGUA) has defined 757 hydrological basins, which are organized into 37 hydrological regions, which in turn are grouped into 13 hydrological-administrative regions for administrative purposes.

On the other hand, in underground water resources, Mexico has 653 aquifers. These resources play an increasingly important role in the socio-economic development of the country. $39.1 \%$ of the total volume granted is for consumptive uses. Regarding the availability of these resources, since 2001 CONAGUA has been carrying out identification, delimitation and calculation of availability studies for each aquifer, resulting in that as of 2018, of the 653 units, 105 aquifers are reported in a state of overexploitation.

In accordance with the above, it is understood that fresh water and the related ecosystems that supply and renew the water that the population needs, have been deteriorating and the hydrological cycle has been altered due, among other causes, to the waterproofing of the soil in the main water recharge areas.

The objective of this study is to offer a practical, low-cost and simple-application methodology that allows the identification of potential water recharge zones. This methodology seeks to integrate knowledge

technical and scientific through the implementation of tools such as geographic information systems (GIS). GIS emerged in the seventies, as a result of the combination of various factors that converged to give rise to the development of the first information systems, these factors are mainly two; the growing need for geographic information, its management and optimal use, and the appearance of the first computers.

\section{Methodology to be developed}

The Tropical Agronomic Center for Research and Education (CATIE), of Costa Rica published in 2009 the methodological guide for determining potential areas of water recharge in hydrological basins. Where it defines as recharge the process in which the liquid coming from outside the contour that limits it is incorporated into an aquifer. The sources of this recharge may be different, from infiltrations caused by rain through surface runoff, to the transfer of water from another aquifer (Custodio, 1998). The site where the recharge occurs is called the recharge zone and they are sites where the infiltration capacity is high.

Aquifer recharge occurs mainly through precipitation in soils with high infiltration capacity or superficially permeable rocks. Aquifer recharge zones may or may not be at great distances from where they are used (Losilla, 1986). It is important to locate the areas that, due to their characteristics, facilitate such recharging; that is, to identify the sites that offer the greatest water recharge contributions and, within these, those that due to their specific characteristics are likely to reduce their recharge potential when subjected to management other than their capacity. These areas are called critical water recharge zones (INAB 2003).

\section{Factors to consider when recharging}

According to the National Institute of Forests (INAB), recharge depends essentially on precipitation, surface runoff and its flow, in addition to soil permeability, moisture content, intensity and amount of rainfall, as well as of the drainage pattern of the basin. On the other hand, the slope of the terrain must also be considered, which is a very relevant factor since very steep surfaces favor runoff while slopes that are not very steep retain water for longer, which helps infiltration (INBA, 2003).

\section{Location}

The Toluca Valley aquifer is located within the limits of the State of Mexico, it is part of the upper basin of the Lerma River, it is located in the southern quadrant of the Mexican plateau and limits to the north with the AtlacomulcoIxtlahuaca aquifer, at the south through the center of Tenango, south west of the Nevado de Toluca volcano. It covers an area of $2,738 \mathrm{~km} 2$. 
The Toluca valley has a high groundwater potential which has been diminished by the export of large volumes through the battery of wells of the Lerma system to supply Mexico City, as well as by local exploitations for its development. The extraction of the resource has already exceeded its potentiality, that is, the amount of the annual average recharge, in the face of an everincreasing demand, which is reflected in a drop in piezometric levels and the formation of cracks in the ground. (CONAGUA, 2002).

According to the latest update of the annual average groundwater availability report for 2015, the Toluca Valley aquifer has a deficit of $136.72 \mathrm{Mm} 3$ / year with an annual recharge of $336.8 \mathrm{Mm} 3$ while it has a demand of 473.47 Mm3. (DOF, 2015).

\section{Spatial data}

The factors to consider in hydric recharge are:

\section{- Weather}

Within this, the factors that most affect water recharge are the amount of rainfall and evapotranspiration, due to the loss of water due to the transpiration of plants and the evaporation of water.

\section{- $\quad$ Floor}

Impervious and compacted soils prevent or hinder infiltration, while permeable soils facilitate recharge. The characteristics of the soil that influence recharge are texture, bulk density, degree of saturation (moisture content), and infiltration capacity.

\section{- Topography}

Determine the contact time between the water and the surface; steep slopes promote surface runoff, decrease contact time, and reduce water infiltration.

\section{- $\quad$ Geology}

The arrangement of different geological materials in the different strata or layers of the soil until reaching the saturated zone (groundwater) can greatly affect the amount of water recharge.

\section{- Vegetation.}

This reduces surface runoff, since it allows a longer contact time of the water with the surface and facilitates the infiltration process; Furthermore, an important percentage of the rain is intercepted by the vegetation cover. In this factor, it is necessary to consider the depth and density of the roots and the retention capacity of the plant canopy.

\section{- Runoff}

Water from rainfall forms surface and underground flows, which are captured by riverbeds.

\section{Prosecution}

In the implementation of the methodology proposed by CATIE (2009), to delimit the potential recharge areas, the following work scheme was carried out.

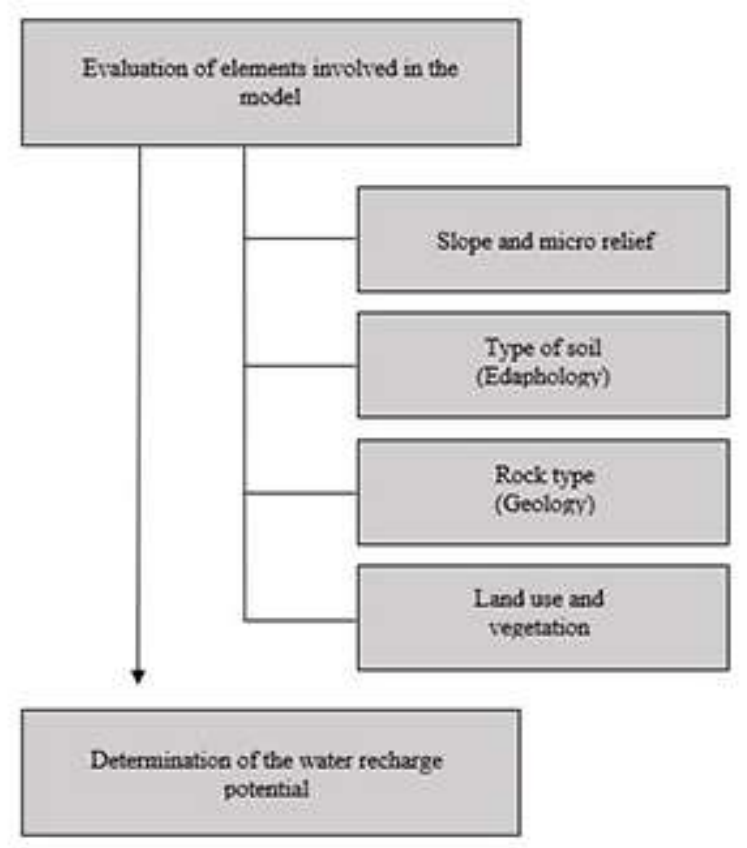

Figure 1. Flow chart for the identification of potential water recharge zones

Source: Own Elaboration

Potential water recharge zones will be delimited by evaluating the following biophysical elements.

$\begin{array}{ll}- & \text { Slopes } \\ - & \text { Micro reliefs } \\ - & \text { Type of soil (Edaphology) } \\ - & \text { Rock type (Geology) } \\ - & \text { Use of land and vegetation. }\end{array}$

SERVÍN-PRIETO, Alan Joel, FRÍAS-RAMÍREZ, José Ernesto, SIFUENTES-MORÍN, Norma Guadalupe and MONTEMAYORTREJO, José Alfredo. Delimitation of potential areas for groundwater recharge in the Toluca Valley aquifer. Journal-Urban-Rural and Regional Economy. 2020 
The weighting for the evaluation of the cartographic information consists of values from 1 to 5 , where 1 corresponds to the lowest value or the least favorable characteristics for recharging to occur. (CATIE, 2009)

\section{Micro relief}

For this section, the digital elevation model (MDE) was used, with a resolution of 30 meters per pixel generated by the National Institute of Statistics and Geography (INEGI). Later, the weighting of the elements was carried out, resulting in what was shown in figure 2.

In relief, flat, concave, and convex surfaces can be identified. When talking about convex surfaces, the water moves by dispersing in different directions, while on inclined flat surfaces the path of the water follows almost parallel directions and finally on concave surfaces it moves concentrating in the lowest place (UNESCO 1986).

Therefore, it can be inferred that, in reliefs with high elevations, steep and rapid surface runoff, the infiltration and recharge process decreases and the erosion and compaction processes of the soils accelerate; this indicates that the relief affects negatively. On the contrary, in places with flat, semi-flat and concave reliefs, the infiltration and hydric recharge process is favored by allowing a longer contact time of the water with the soil.

\section{Pending}

It can be said that in sites with steep or steep slopes, the speed of runoff increases, which modifies soil conditions, recharge capacity and susceptibility to erosion; on the contrary, on gentle slopes, the water moves slowly and remains in contact with the ground for a longer time, which favors the infiltration process.

\begin{tabular}{|c|c|c|c|}
\hline Micro relief & $\begin{array}{l}\text { Pending } \\
(\%)\end{array}$ & $\begin{array}{c}\text { Possibility } \\
\text { of } \\
\text { recharging }\end{array}$ & Value \\
\hline $\begin{array}{l}\text { Flat to almost flat, with or } \\
\text { without roughness }\end{array}$ & $0-6$ & $\begin{array}{l}\text { Very } \\
\text { high }\end{array}$ & 5 \\
\hline Moderately wavy or concave. & $6-15$ & high & 4 \\
\hline Wavy / concave. & $15-45$ & Half & 3 \\
\hline Steep. & $45-65$ & Low & 2 \\
\hline Strongly steep. & $>65$ & Very low & 1 \\
\hline
\end{tabular}

Table 1 Weighting of the slope and micro relief Source: Own Elaboration

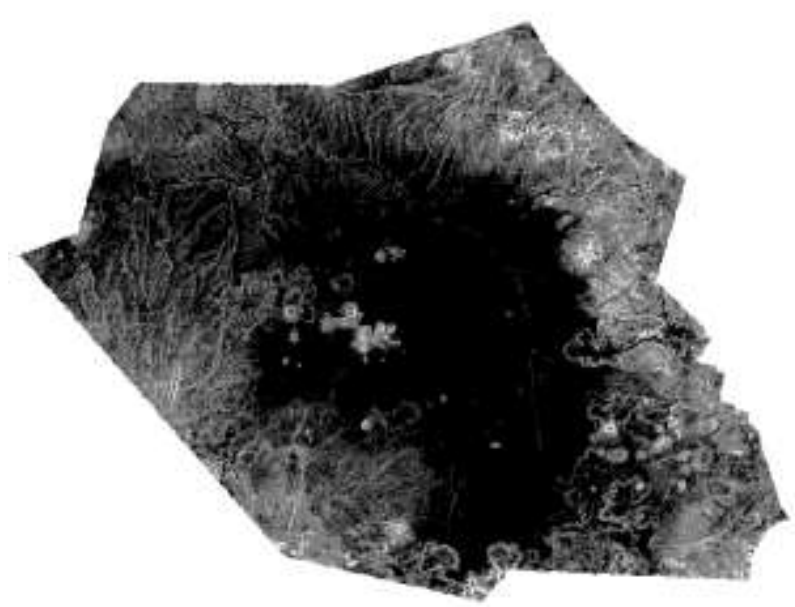

Figure 2 Classification of the slope and micro relief Source: Own Elaboration

\section{Soil type (Edaphology)}

The cartographic information that served as input in this section was generated by the INEGI in the period of 2013, the edaphological data contains information associated with the soil groups that exist in the national territory, scale 1: 250,000 . Soil type evaluation is important as it re fl ects its texture, porosity, permeability and compaction. The water recharge zones must be highly permeable to ensure a high infiltration capacity; In other words, in soils with coarse, porous texture, good levels of hydric recharge occur.

On the contrary, soils with a fine texture, clayey, heavy and compacted prevent or hinder water recharge. In order to find potential water recharge zones, it is necessary to evaluate in the field, together with local actors, two elements that influence the permeability of the soil: the texture and the infiltration capacity.

\begin{tabular}{|c|c|c|}
\hline Soil texture & $\begin{array}{l}\text { Possibility } \\
\text { of } \\
\text { recharging }\end{array}$ & Value \\
\hline $\begin{array}{l}\text { Sandy to sandy loam soils, with coarse } \\
\text { to medium aggregate or particle sizes, } \\
\text { with very rapid infiltration capacity. }\end{array}$ & Very high & 5 \\
\hline $\begin{array}{l}\text { Loamy soils, with equal parts of sand, } \\
\text { silt and clay, with rapid infiltration } \\
\text { capacity. }\end{array}$ & high & 4 \\
\hline $\begin{array}{l}\text { Silty loam soils, with fine medium- } \\
\text { sized particles, with moderate to } \\
\text { moderately rapid infiltration capacity. }\end{array}$ & Half & 3 \\
\hline $\begin{array}{l}\text { Clay loam soils, combination of silt and } \\
\text { clay, with fine particles, heavy soils, } \\
\text { with samples of compaction, with slow } \\
\text { to moderately slow infiltration capacity. }\end{array}$ & Low & 2 \\
\hline $\begin{array}{l}\text { Very heavy clay soils, with very fine } \\
\text { particles, compacted, with very slow } \\
\text { infiltration capacity. }\end{array}$ & Very low & 1 \\
\hline
\end{tabular}

Table 2. Weighting of the soil according to its texture Source: Own Elaboration 


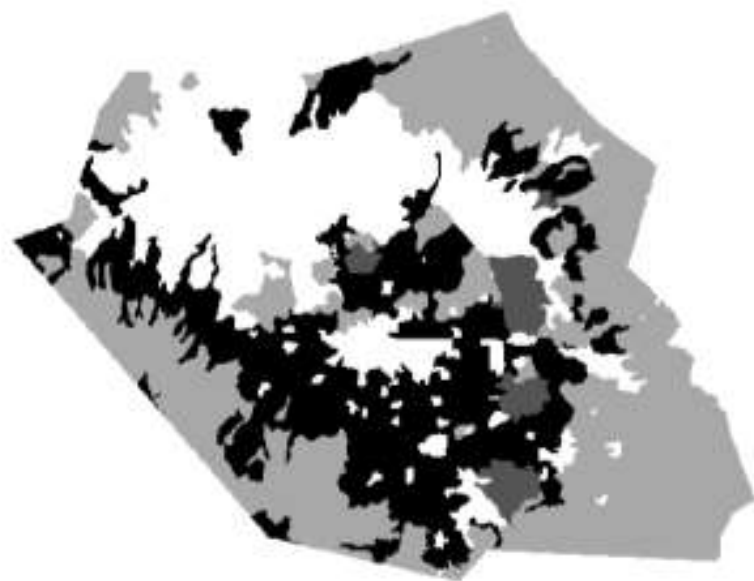

Figure 3. Classification of the soil according to its texture Source: Own Elaboration

\section{Rock Type (Geology)}

The Mexican Geological Service (SGM). It has geospatial information updated to 2005 on lithology issues. Geological charts are used in exploration and generation of mainly mining projects, in regional or local geological research studies. The work scale was 1: 250,000 . It is important to take into account the characteristics of the rocks since their recharge capacity is determined by their porosity and permeability. Hard rocks with fine pores are not conducive to recharge; while, soft or permeable rocks, with macro pores, faults or fractures do favor the recharge of aquifers.

\begin{tabular}{|l|l|l|}
\hline Rock type & \multicolumn{1}{|c|}{$\begin{array}{l}\text { Possibility of } \\
\text { recharging }\end{array}$} & Value \\
$\begin{array}{l}\text { Very permeable, very soft rocks, made } \\
\text { up of crystals or coarse aggregates, } \\
\text { with interconnected macro pores; for } \\
\text { example, coarse sand, pumice, gravel } \\
\text { or gravel. }\end{array}$ & 5 \\
\hline $\begin{array}{l}\text { Soft, permeable rocks, made up of } \\
\text { crystals or medium aggregates, with } \\
\text { interconnected pores; for example, } \\
\text { fine sand or sandstone with little } \\
\text { cement. }\end{array}$ & high & 4 \\
\hline $\begin{array}{l}\text { Rocks moderately permeable, semi } \\
\text { soft, with regular connection between } \\
\text { pores. }\end{array}$ & Half & 3 \\
\hline $\begin{array}{l}\text { Poorly permeable rocks, a little hard, } \\
\text { moderately compacted, made up of } \\
\text { fine particles, with the presence of } \\
\text { fractures }\end{array}$ & Low & 2 \\
\hline $\begin{array}{l}\text { interconnected; for example, the } \\
\text { combination of gravels with clays. }\end{array}$ & Very low & 1 \\
\hline
\end{tabular}

Table 3 Weighting of the soil according to the type of rock Source: Own Elaboration

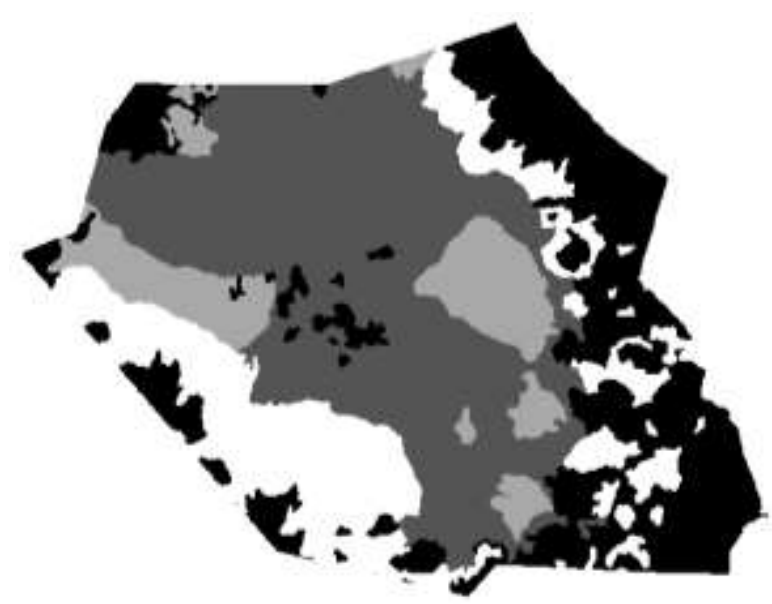

Figure 4 Classification of the soil according to its type of rock

Source: Own Elaboration

\section{Land use and vegetation}

In INEGI, geographic information related to land use and vegetation was generated from the interpretation of LANDSAT-8 satellite images with $30 \mathrm{~m}$ resolution. The result was series VI with an update period from 2014-2017, on a scale of 1: 250,000. The presence of several strata of vegetation cover favors hydric recharge and helps to conserve the characteristics of the soil that also favor recharge. When talking about strata, three are basically considered: trees, shrubs and herbs. All of them guarantee a better vegetation cover, a greater quantity of organic matter, greater water retention and greater infiltration.

\begin{tabular}{|c|c|c|}
\hline Vegetation (\%) & Possibility of recharging & Value \\
\hline$>80$ & Very high & 5 \\
\hline $70-80$ & high & 4 \\
\hline $50-70$ & Half & 3 \\
\hline $30-50$ & Low & 2 \\
\hline$<30$ & Very low & 1 \\
\hline
\end{tabular}

Table 4. Weighting of the soil according to its vegetation cover

Source: Own Elaboration

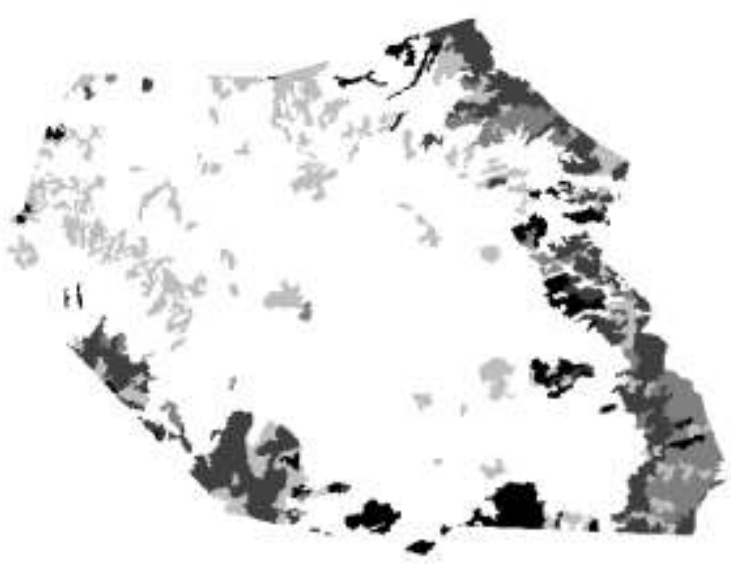

Figure 5 Classification of the soil according to its vegetation cover

Source: Own Elaboration

SERVÍN-PRIETO, Alan Joel, FRÍAS-RAMÍREZ, José Ernesto, SIFUENTES-MORÍN, Norma Guadalupe and MONTEMAYORTREJO, José Alfredo. Delimitation of potential areas for groundwater recharge in the Toluca Valley aquifer. Journal-Urban-Rural and Regional Economy. 2020 
It is necessary to detect the uses that, due to their characteristics, favor the infiltration of water, such as silvopastoral and agroforestry systems, the use and incorporation of organic matter, or crop associations.

It is also important to recognize those crops that affect soil characteristics, make infiltration difficult and favor evaporation, compaction and surface water runoff, such as intensive agriculture without conservation works, extensive livestock farming, conventional tillage, or use of agricultural machinery.

\begin{tabular}{|l|l|l|}
\hline \multicolumn{2}{|l|}{ Uso del suelo } & \multicolumn{1}{l|}{$\begin{array}{l}\text { Posibilidad de } \\
\text { recarga }\end{array}$} \\
\hline $\begin{array}{l}\text { Forest where the three strata occur: trees, } \\
\text { shrubs and grasses or dense grass. }\end{array}$ & Very high & 5 \\
\hline Agroforestry or silvopastoral systems. & high & 4 \\
\hline $\begin{array}{l}\text { Cultivated land with soil and water } \\
\text { conservation works. }\end{array}$ & Half & 3 \\
\hline $\begin{array}{l}\text { Cultivated land without any soil and water } \\
\text { conservation work. }\end{array}$ & Low & 2 \\
\hline $\begin{array}{l}\text { Agricultural land with intensive } \\
\text { management. }\end{array}$ & Very low & 1 \\
\hline
\end{tabular}

Table 5. Weighting of the soil according to its use. "Own Elaboration"

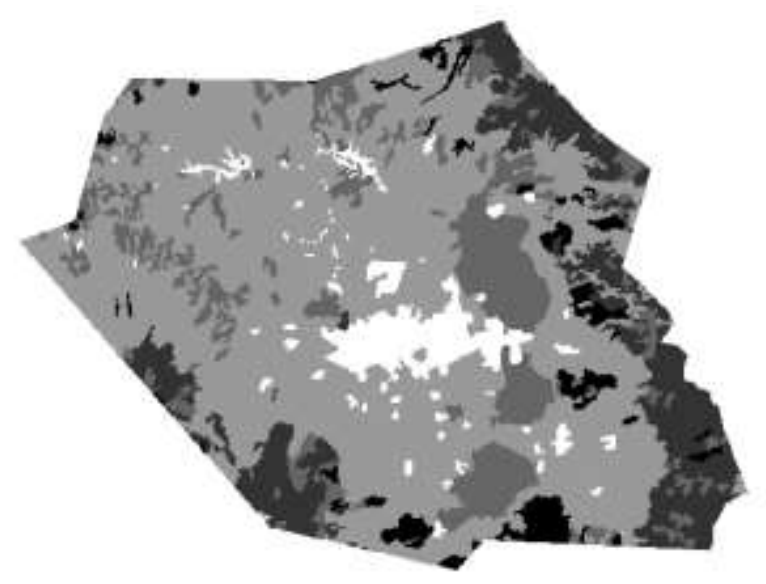

Figure 6. Classification of the soil according to its use. "Own Elaboration"

\section{Determination of recharge potential}

Finally, and to determine the water recharge potential, equation 1 (CATIE 2009) is used, in which each of the elements of the model is replaced by the respective values obtained in the evaluation of the elements:

$Z R=[0.27($ Pend $)+0.23(T s)+0.12(T r)+0.25$

$(C v e)+0.13(U s)]$

\section{Where:}

$\begin{array}{ll}- & \text { Pend: Slope and micro relief } \\ - & \text { TS: Soil type } \\ - & \text { TR: Rock type }\end{array}$

\section{- $\quad$ CVE: Permanent vegetation cover - $\quad$ US: Land uses}

To determine the possibility of water recharge in a given area, once the characteristics of the area are evaluated considering the elements of the methodology and the tables designed for this purpose (evaluation tables), each result obtained is multiplied by its corresponding factor and the elements are added. This sum corresponds to a number within a range of water recharge possibilities. The assignment of relative weights to each element is made according to the importance of that element in the water infiltration process; In other words, the criteria that most favor the infiltration of water into the soil are the most important.

The indicators in the previous equation correspond to the relative weights agreed for the sub-basin. In this assignment, it is convenient to have the experience of extension agents working in the area.

\begin{tabular}{|c|c|}
\hline Possibility of recharging & Value \\
\hline Very high & $4.1-5$ \\
\hline high & $3.5-4.09$ \\
\hline Half & $2.6-3.49$ \\
\hline Low & $2-2.59$ \\
\hline Very low & $1-1.99$ \\
\hline
\end{tabular}

Table 6 Potential for water recharge according to the model

Source: Own Elaboration

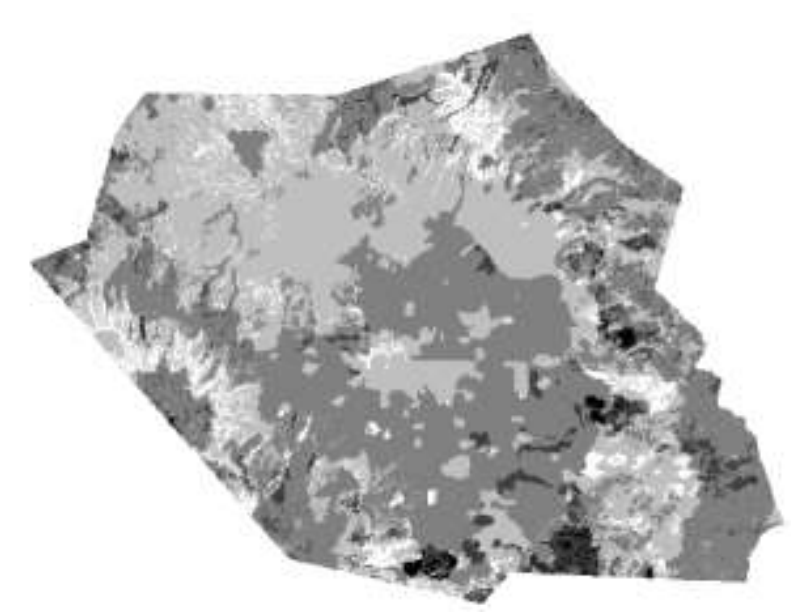

Figure 6 Potential for water recharge Source: Own Elaboration

\section{Results}

The map of potential water recharge of the Toluca Valley aquifer was based on the mapping units: soil type, land use and vegetation, geology and slope. 
Each mapping unit was evaluated with the weightings proposed in the methodology and, later, with the help of the raster calculator tool of the QGIS 3.10 software, the model was applied that allowed to generate the map of the areas with potential recharge of the aquifer ( Figure 6).

It should be noted that the overlapping of mapping units is a viable technical alternative to identify and define the recharge potential in aquifers. The map shows that in the aquifer there are five categories of possibility of water recharge, although the moderate possibility prevails $(59.4 \%)$, followed by a low possibility of occurrence of recharge $(21.0 \%)$, very low possibility ( $16.7 \%)$, high possibility $(1.6 \%)$ and very high possibility (1.2\%).

Consequently, due to its physical characteristics, the aquifer is classified as regular so that water recharge or infiltration of water into the soil occurs, since $80.4 \%$ of the total area is located in the categories of moderate and low possibility of occurrence. of hydric recharge. In other words, the amount of water that precipitates and remains available in the subbasin has moderate to high possibilities of infiltrating and recharging the aquifers.

\section{Conclusions}

According to the results obtained at the end of the investigation, it is concluded that the proposed methodology and the GIS allow the delimitation of areas with recharge potential. It is also recommended to continue improving the method using larger-scale cartographic information, in order to obtain accurate results and greater satisfaction.

\section{References}

Boletín Hidrológico No. 50, Región Hidrológica No. 12 Dirección de Hidrología, SRH, 1970.

Conagua. 2003. manual de agua potable, alcantarillado y saneamiento - maPas.

Conagua. 2005. estudio de Transversalidad de las Políticas Públicas Federales en el sector Hídrico.

Conagua. 2007. análisis de la información del agua de Censos y Conteos 1990 a 2005.
Custodio, E. y Herrera, C. (2000): Utilización de la relación $\mathrm{Cl} / \mathrm{Br}$ como trazador en hidrología subterránea. Boletín Geológico y Minero. Vol. $11-4,49$.

Custodio, E. (1993): "Coastal aquifer salinization as a consequence of aridity: the case of Amurga phonolitic massif, Gran Canaria Island". Study and Modelling of Salt Water Intrusion. CIMNE-UPC. Barcelona: 81-98.

Custodio, E. (2007): "Groundwater in volcanic hard rocks". In J. Krásny and J.M. Sharp Jr., Groundwater in Fractured Rocks. Intern. Assoc. Hydrogeologists, Selected Papers 9. Taylor \& Francis, London: 95-108.

Custodio, E. (2010): "Estimation of aquifer recharge by means of atmospheric chloride deposition balance". Contributions to Science, 6 , 1, 81-97.-68.

INEGI. 2013c. Cartografía topográfica escala 1:250 000 y $1: 50000$.

INEGI. 2013c. Cartografía edafológica escala $1: 250000$ y $1: 50000$.

INEGI. 2017c. Cartografía uso de suelo y vegetación escala 1:250 000 y 1:50 000 .

Herrera, I.R. \& Orozco, E. O., 2010: Hidrogeología de Ojo de Agua, cuenca sur de la ciudad de Guatemala. Rev. Geol. de Amér. Central, 42: 85-97.

Losilla, M., 1986: Mapa hidrogeológico del valle central, Costa Rica. Rev. Geol. de Amér. Central, 4: 97-100. 